\title{
TOURISM AND ITS ROLE IN PROMOTING SUSTAINABLE FOREST MANAGEMENT IN SERBIA
}

\author{
Suzana Đorđević - Milošević*, \\ Jelena Milovanović \\ Singidunum University, \\ Belgrade, Serbia
}

\begin{abstract}
:
Assessing forest contributions to local economies and well-being in Serbia is possible only in a qualitative way by exploring related rural cultures. Knowledge and experience in using forest ecosystem services show that the main economic benefits of forests for employment and the value of outputs for local communities were declining through history, while the social and cultural benefits are increasing. Yet, the assessment of forests perceptions nowadays shows that local communities rarely consider forests as a development potential, but rather an immediate supply. A short survey was made to understand the perception of rural and urban people and learn to which extent there is a set of traditional priority benefits possible to expand towards untraditional, such as tourism and recreation to add value. The factors influencing local community decisions on the most important forest benefits were also explored. Mapping value chains for the most important forest products was the following. Firewood, non-wood forest products (NWFPs), game products, and rural tourism value chains were viewed through a prism of potential tourism supply chains. Finally, financial support to rural development was assessed to find possible interactions of sustainable forest management and tourism by supporting shortening and strengthening its supply chains in afforested rural areas or allusions to the tables or illustrations..
\end{abstract}

Keywords:

community perception, forest ecosystem services, rural tourism.

\section{INTRODUCTION}

Forest ecosystems can provide a variety of socio-economic benefits. Ranging from those easy to quantify (linked to measurable forest production) to the line of contributions to society which, although hard to measure, might represent fundament of rural and national economies in afforested territories. Capacity to estimate value of forests ecosystems services is still low in many countries (FAO, 2015), as much as a capacity to understand reverse effects of economic activities based on forests. Serbia is not the exception. This shortage is the cause of serious underestimation of possible forests contribution to rural economy rehabilitation, but also limits introduction of sustainable forest management.
Correspondence:

Suzana Đorđević - Milošević

e-mail:

sdjordjevicmilosevic@singidunum.ac.rs 
For Serbia this is a critical issue due to the expressed rural poverty and severe threats forests are exposed to (Šijačić-Nikolić et al., 2014, 2019). Diversification of incomes by employing unused forest ecosystem services instead of continuing their simplified (and destructive) exploitation is necessary. Tourism in Serbian countryside is increasingly seen as a potent activity which can contribute to diversification and facilitate resurrection of its stumbled economy (Đorđević-Milošević, 2020). The priority is to answer the question "Which forest ecosystem services should be employed to provide sustainability of tourism in afforested rural areas, as well as "Can tourism contribute to rural development while promoting sustainable forests management and how?"

\section{LITERATURE REVIEW}

Sustainable Forest Management (SFM) is a management regime that integrates and balances social, economic, ecological, cultural, and spiritual needs of present and future generations (Wilkie at al., 2003). UN Resolution $62 / 98$ confirmed "SFM as a dynamic and evolving concept that aims to maintain and enhance the economic, social and environmental value of all types of forests, for the benefit of present and future generations." The forest should not be used beyond its long-term capacity for production of wood and non-wood forest products (NWFPs)(MCPFE, 1993). Therefore, multiplying benefits from forest is required and it starts with the selection of additional economic activities which can support livelihoods of forests dependants (Đorđević-Milošević and Milovanović, 2020b, 2014, 2012), while sustaining its survival. Efforts to sustainably manage forests are meaningful and long lasting, only if the society sees the economic benefits of conserving forests (Wickramasinghe, 2012). Nature-based tourism rapid growth is seen as an opportunity for attracting interest of society to preserve forests as much as a chance to decrease the pressure of its destructive consumptive timber uses (Phumsathan et al., 2017). Ecological uniqueness, the abundance of flora and fauna, and beautiful landscapes with a potential for diverse recreational activities in accessible, safe, and pristine environment, which is easily attributed to Serbian forests, might not be sufficient to claim that tourism in Serbia based on them will contribute to SFM, which is a must. Stepping back to check all major forest benefits and how they fit within seems inevitable.

\section{METHODOLOGY}

In this paper people's perception of forest benefits using questionnaires for urban and rural population was explored to identify those which could be earmarked as the most important on a small sample of 20 respondents, but targeting parts of the population which actively communicate with forests in their daily life (urban and rural). Persons connected with forestry by profession were excluded. The questions were open, allowing participants to respond according to their knowledge about services provided by forests and not evaluating the enlisted set of services provided by the examiner.

Then selected products/services value chains were mapped. Their structure was captured and visualized to show the main flows of products, while single links of special importance were explored. In-depth interviews were conducted with various stakeholders to obtain data for mapping (local inhabitants in afforested areas, forests enterprises' representatives, civil society organizations (CSOs), tourist services providers, local governments, academia, law enforcement agencies etc. The targeted SWOT analysis of the rural tourism was conducted to highlight possible hubs for forests products and services supply chains. Financial support available for activating opportunities was assessed primarily through exploring actual rural development policy.

\section{RESULTS AND DISCUSSION}

\section{Perception of forests by rural and urban people}

Forest contributions to local economies and well-being highly correlate with rural cultures. When discussing forest benefits in Serbia, different lists could be compiled depending on respondents. Differences in perception of forest values derive from different lifestyles. As expected, urban population has enlisted ecological function 
of purification of air as the top one, then social function of recreation as the second one and the source of wood and "wild fruits" (edible, medicinal and aromatic plants (Ratknić and Milovanović, 2016) and mushrooms) as the third one. Respondents from the rural areas placed firewood as the top one, game meat as the second one and non-wood forest products as the third one. In marginal areas, in traditional rural environments with elderly population forests are providers of energy and food, materials for housing, maintaining health. For the population from the local urban centers, forests are places for employing the workforce. For inhabitants of remote abandoned rural areas, forests are a source of survival that is capable to mitigate risks of extreme poverty (Đorđević-Milošević and Milovanović, 2020c). While poor villagers of suburban areas of Belgrade will collect deadwood from public forests around to survive winter, others will cut their own or public forests (legally or illegally), collect "wild fruits" or hunt wild game to conserve them for their own use and provide wood security in South-East Serbia, while others will go beyond their own bare necessities and exploit some to sell it to a more remote user (in areas with strong processors such as Šumadija, Western Serbia, etc.), to obtain money for other needs. The factors that affect local community decision to consume forest product or service are usually double - satisfying their own needs (subsistence) and satisfying someone else needs (cash products).

Urban population mentioned supply function as important, yet ranking it lower than rural, which implies that their ability to provide food and medicines seemingly from other sources than the forest is preventing them from understanding supply (economic) forest service. For poor, using forest supplies is a necessity and for them it is a top priority not just considering forest services, but sometimes in general. These might also include medicines and aromatic substances, and regular energy of wood, which appears priority for the rural population in general (including also small urban centers with no other energy supply alternatives).

The support service implies the creation of necessary resources for the smooth functioning of ecosystem functions, including: the cultivation of fertile soil and its stabilization, regulation of parasites, seed extraction, pollination, and stabilization of ecosystems for which understanding of their importance depends on knowledge, which is not expected to be present in population in general, besides the professionals. Taking regulation functions as granted is common in Serbia, since enabling regulation of natural processes, such as reduction of the greenhouse effect, purification of water, air, and soil is considered as impossible to vanish.

Forest spiritual and health-recreational services mean the "service" of staying in nature, feelings, and possibilities of walking, enjoying the greenery, possibilities of inspiration, and learning about the natural history. These are advanced needs which are coming to be fulfilled once the necessities are in place and life sustained and safe. For that reason, these kinds of forest services are sitting so high on priority lists of Serbian urban population and are not among three of top importance for rural population. Of course, depending on the time of year, the examiner might get different answers. Just before Christmas, respondents mention some spiritual functions of forest such as tradition of cutting wood and harvesting branches with dry oak, placing it in first 3 important forest products. On the other hand, some respondents might get forest as an inspiration while they are walking through some villages in Serbia which have art colonies during summer.

Following these findings, further analysis was done to learn about the factors influencing local community decisions on the most important forest benefits

\section{Factors influencing local community decisions on the most important forest benefits}

The factors influencing local communities decision to select a natural resource for sampling and possibly to incorporate it in their social-ecological systems are usually double - satisfying their own needs and satisfying other people's needs, no matter if the provided good or service is paid or not.

Applying Ecological appetency hypothesis (EAH), conceived by Feeny (1976) (Endara and Coley, 2011), to ethno-biology, the plants that are the easiest to find have a greater cultural importance and richness of uses. In Serbia, these are widespread fruit, mushroom, medicinal and aromatic plants, timber, plant material used for making natural dies, processing leather and majority of wild game and non-biological resources such as stone, clay, gravel, send etc. In this case once resources become scarce or depleted, local communities with economy based in collection of "wild fruits" switch their main interest to more scattered resources or leave the area. This relates also to the demography and skills of local communities, availability of equipment and vehicles, accessibility of locations through local infrastructure or naturally (easily passable terrain of not-seep, wet, grown 
in the wilderness with thick vegetation etc. or with easy to go terrain etc.). For this reason, the best conserved forest ecosystems are those in mountain remote rural areas, where infrastructure in Serbia is generally weaker such as in Eastern and South-Eastern Serbia.

After years of appearance of climatic extremes announcing obvious climate change (Milovanović et al., 2019), current native vegetation in the majority of forest areas of Serbia represents a result of both past management and natural causes, which led to biodiversity erosion. Of course, changes are most obvious in species which are most heavily or inappropriately used such as for berries, mushrooms and destruction of bushes and mycelia and game species (non-selective hunting misbalancing population structure). These products are mostly sold as raw materials reaching small price on the immediate market, while main profit is provided on remote markets after processing. Adding value through tourism might help them to be more sustainably managed through decreased pressure on the resources due to higher income from processed materials.

Maldonado et al. (2013) reported on correlation between the environmental availability of a resource and its importance. The traditional construction was highly dependent on natural materials and their environmental availability. The new one is more influenced by the economic status. If it is a material from the immediate nature, it is more connected to the poverty of the owner, who couldn't afford to purchase industrial products deriving from remote places. This is not necessarily negative, since it's already noted that local construction habits of using, for instance, timber for erecting buildings, besides using firewood, represented one of the highest pressures on native vegetation (Dahdouh-Guebas et al., 2000). Nowadays, when the use of forest resources for selling goods outside the region started prevailing, availability is not crucial for exploitation - local communities with expressed poverty will pick whatever they can sell, no matter in which quantities these exist. Even one kilogram of well-paid mushroom will move people to forests. Of course, people will look for all species which they can sell, no matter if they are rare or not. If purchase is organized, then pressure is higher, and pickers are coming from remote places, even out of the region.

The local importance of species may change in response to different environmental conditions (rainy summers and autumns with more mushrooms, dry summers decreasing quantity of medicinal plants etc.). Territories with big fluctuations of weather conditions are never those where local communities rely too much on non-wood products in their economy, yet interest for some species will remain for their own consumption, but just in more traditional areas where knowledge was transferred, or suburban areas, where urban population look for the relaxation and where picking local wild plants or mushrooms and hunting and fishing have multifunctional role. Although the quantities they collect are minor, the benefits are high, but more from social point of view.

Further analysis was done to learn about the priority products through mapping value chains for firewood, non-wood forest products and game products (these value chains are not presented in this paper, but more detailed information can be obtained from the authors). Rural tourism value chain was mapped to discover possible hubs for local supply and is based on the aforementioned value chains.

\section{SFM - based rural tourism SWOT analysis and value chain map}

SWOT analysis of the rural tourism in Serbian afforested areas provides the following main features: On the strengths side we can put various types of forests, high biodiversity (Milovanović and Đorđević-Milošević, 2016), plenty of NWFPs (eatable greens, fruits, mushroom, medicinal plants etc.) and solid game populations (meat and trophies) providing raw material for quality products in (large extent) pristine environment and plenty of still well preserved natural habitats (mainly mountainous). Weakness in rural tourism of Serbia is mainly on the infrastructure side. Bad local road networks, lack of sewage networks and shortages in electricity and water supply in most attractive rural areas puts further development of rural tourism under the question. Disturbed countryside due to bad waste management or lack of it, lost original architecture, almost savage urbanization and capturing waters for electricity production, leading to devastation of small watercourses as much as intensive cutting of forests have already swept chances for tourism development in any sense for many rural areas. On the opportunities side we can put the existence of the variety of local gastronomy traditions and traditional products made of forest fruits, game meat, medicinal plants, mushrooms and wild vegetables on relatively small space. Recently regulated home preserves production and marketing makes this production 
legal which has opened space for direct marketing as much as rural tourism. Threats are represented with the continuing depopulation, aging, and degradation of infrastructure in rural areas, but also lack of institutional support including control as much as complicated access to financial support to investments in tourism. Threats imposed by diseases such as Covid-19 are indisputable, but rural space and forest resources are also under the threat of animal and plants diseases and pests, fires and pollution which are decreasing their value (in quantity and quality). Finally, there is a lack of money for investments in forest products and services value chains. Therefore, tourism development is slowing down in rural areas and there is a decline in the interest of tourists for inland tourism.

At the same time, the fact that most of forest products at the moment "travel" through long weak value chains, could be observed from both sides of the opportunity-threat side. Namely, if opportunities are not used to strengthen these value chains by providing hubs in local tourism to shorten them, present exploitation will most likely bring them to the end, since low prices on markets push local forest owners e.g. beneficiaries to exploit them more intensively to survive. On the other side, expanding interest for tourism in rural areas might bring to the end hunger for more materials to be extracted, if demand and offer are rational. Nevertheless, forests of Serbia might benefit from tourism development since it provides hubs for their product and services. International principles of forestry and environmental protection policy, which are set out in Agenda 21, have indicated that SFM is a responsibility and "a job of multi-actors" from different sectors and on diverse levels. Therefore, rural development window should be opened for financing SFM related activities.

Surprisingly, explored value chains for forest products are rarely linked with the rural tourism. The existing rural tourism in Serbia is too much agro-tourism with adjacent free and self-organized activities and not an integrated product which is based on partnerships in local communities and harmonized use of natural and cultural heritage on disposal. Even food supply chains are long in large extent. For that reason, the only benefit which locals can claim is the accommodation and food cost. Besides mismanagement of the food supply chains, which is providing far away from efficient utilization of local potentials for its production through optimal short value chain, supply of services provided (or possibly provided) by local ecosystems is underutilized or not used at all. Tourists mainly entertain themselves in nature with providing nothing in return but risks for the habitat and its flora and fauna, while local communities remain watching silently how their space is used, their lives disturbed and opportunities for income generation missed.

Ideally rural tourism might include various forest ecosystem services and become an ideal platform for supporting sustainable forest management (Fig. 1). However, such tourism should have destination management organization which will provide hub for individual business in the HoReCa sector (Hotel/Restaurant/Catering).

Figure 1. Forest-based rural tourism value chain map

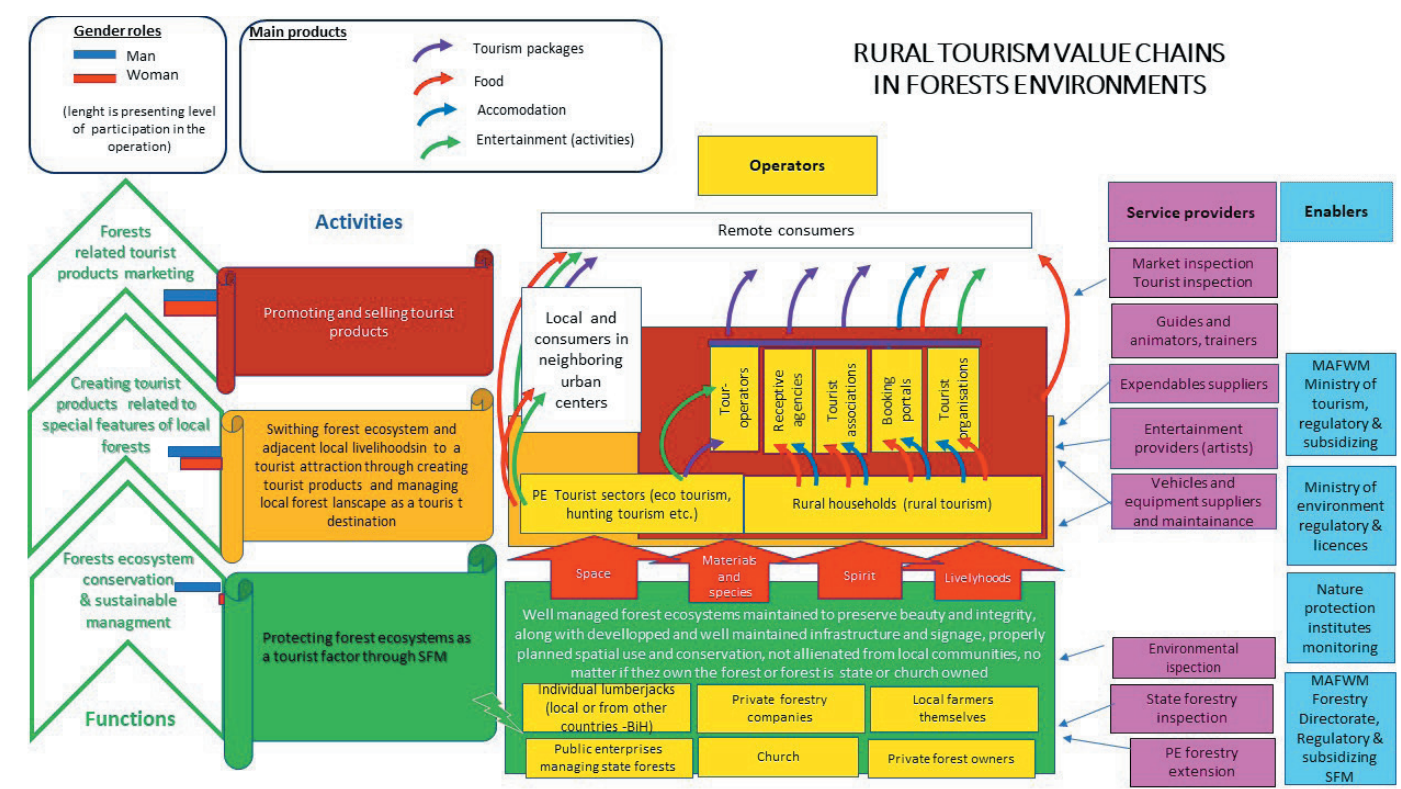

Source: (developed by the authors) 
In the middle of presently frozen development of rural tourism, the Government is introducing a new law on taxes for using public goods, exposing local communities and their guest to additional costs which, although intended to support sustainable natural resources management seems to be in no way returned to development of sustainable practices. How this new circumstance will influence sustainable forest management concept it's a matter of careful monitoring and critical analysis in the years to come, but support to SFM and support to rural development have a very useful meeting point in rural tourism. The exercise has to employ support to rural economy diversification (axis 3), agro-environmental measures (axis 2) and support to local partnerships through LEADER approach. There is a space for employing Axis 1 Rural Development measures as well, since rural tourism needs to be supported by strong processing and primary food production which should not remain only within agriculture. The place of both men and women and other marginalized groups in such organized complex value chain is reserved, since all skills of local community and more must be employed for success.

\section{Financial support to SFM - based rural tourism}

Looking for sources for financing SFM should not remain within forest sector. Incorporating different stakeholders into creating forestry policy (Šijačić-Nikolić et al., 2017) will not be sufficient if forests and forestry issues do not become part of processes of creating policies or at least the permanent concern of nature protection, rural development or employment policies for instance.

Economic instruments for forest protection are a minor part of the environmental protection budget of the Republic of Serbia. Other sources include municipal budgets, revenues from charges and fees, commercial sector funds, and ad hoc support from donations and international aid. These are foreseen to support the rational use of resources as an integral part of the overall development strategy, especially of technological development. They should provide for sound sources of financing the environmental protection defined by law and market based on efficiently indicating advantages of the environmental protection (Đorđević-Milošević and Hyvaerinen 2020).

Possible financial support to SFM - based rural tourism might be available from two sources - those defined by the National Program for Rural Development (NPRD, 2018) and those defined within the Serbian IPARD program (IPARD, 2014). Some new measures implementing social and ecological (and economical) forest functions could be created for the beginning, even if they do not exist in EU countries practice, but it's a good approach if first those which were implemented, and which can offer lessons learned to Serbian practitioner should be selected. Exercising such measures can start within the NPRD and then to be transferred to IPARD gradually with the increase of the capacity of administration (payment system). What is good about the chosen rural development measures in Serbia is that the majority of them can influence indirectly forest management and help raising its sustainability.

The best chance to get one of indirect measures to support SFM at the moment is incentives through IPARD program to diversify income and improve quality of life in rural areas. Namely progress made in the M7 measure accreditation process - "Diversification of agricultural holdings and business development" is recently presented (the beginning of July). This measure belongs to the IPARD II set of measures of the Republic of Serbia for the period 2014-2020, which was adopted by the European Commission (EC) in January 2015. The financial agreement between the Government and the EC was signed in June 2018. The IPARD Program is a good opportunity for introducing the adding value to the NWFP sub-sector in Serbia since it contains double orientation:

- The rural tourism sector (investment in construction, upgrading, adaptation, ongoing maintenance as well as procurement of equipment and promotional activities, with the aim of providing catering services in authentic catering facilities in domestic crafts or rural tourism households).

- The sector of old and art crafts, that is, domestic work (investment in the procurement of equipment - machinery and tools, for the performance of jobs that are considered old and artistic crafts as well as in the promotion of activities).

Tourism value chains with strong local food supply produced in forest ecosystem and agroforestry systems (Đorđević Milošević and Milovanović, 2020a) through "re-wilding" degraded areas etc. might create huge benefits. 
Therefore, it's necessary to simplify procedures for approving afforestation on agricultural land and provide switch from the support from the forestry budget to continuous support through axis 2 types of measures in IPARD, while released money to invest in more local nurseries which will be able to support forest owners to reconstruct more diverse forests with native species. Wild fruits on marginal lands or in zones suitable for tourism development should be supported, where rural population have good chance to add value to these products through developing quality economies based on tourism. Planning of eligibility criteria for the support of investments needed in this sector, should take care to satisfy multiple goals such as environmental ones: conservation of genetic diversity, prevention of erosion, attractiveness of the countryside or social: contribution to the poverty reduction, inclusion - in particular job creation for women and young people representing the surplus of labor on the small farms etc. This will support SFM and decrease pressure on wood for fuel, which is presently the main benefit for rural population in Serbia.

Positive interactions of sustainable forest management and tourism are possible if tourism value chains are enriched with short supply chains of NWFP, game and timber for which incentives should be provided through financing investments in processing (axis 1 /fruits and vegetables, meat, mushrooms and medicinal plants) and diversification (axis $3 /$ for handicrafts and rural tourism including gastronomy and construction of facilities using materials from the immediate nature/local forests resources).

Measure 11 of the IPARD II - Forestry was not planned for the implementation within Serbian IPARD II. Moreover, neither of candidate countries has utilized this one. During the recent discussion over IPARD III measures occurring within the agenda of a workshop in Bečići, Montenegro (the Workshop was held between 10 and 11 April 2019 organized jointly by SWG and the European Commission (AGRI.E5 team, including AGRI colleagues from the respective EU Delegations), and supported by the German International Cooperation (GIZ)), the issue was raised on whether to keep "forestry" measure or not. Even though the majority said that they were unlikely to use this measure, some participants advocated for keeping it. And indeed, Forestry measure 11 is not foreseen for implementation in Serbia yet, although needs for strengthening forestry as much as managing sustainably forest resources is noted as one of the needs.

For accreditation after 2019 (Phase III), forestry might be a component or at least benefit of some, since the following measures will be prepared:

Measure 4: Measures of agroecological (AE), climatic and organic production

Measure 5: Preparation and implementation of local development strategies - LEADER approach

This means that support to the EU LEADER type activities in future could help in large extent to get on board wide public of stakeholders in taking care of SFM. Serbia has plans to provide support to local action groups (LAGs) working in manner of LEADER, first for their operation and planning and later for projects identified within defined priorities. This support will be crucial in making forests an important asset of local development planning at the moment, as could be observed from the analysis of local development strategies, forests seem to be completely marginalized and planning omitted and left to public sector.

Supporting shortening of value chains should be provided through the axis 2 - Support for establishing local partnerships, preferably of the LEADER type, so that not just business partnerships are easily established, but also decision making in strategic and action planning of local communities could be improved and rationalized. Strengthening of supply chains for tourism in afforested rural areas should occur also with the support from the set of AE measures supporting High Nature Value Farming (HNVF) practices (Keenleyside et al., 2010) which will embrace principles of traditional and modern agroforestry and silvo-pastoral practices which can give a new meaning also to the support for afforestation of marginal agriculture lands.

\section{CONCLUSIONS}

Numerous forests ecosystems services of Serbia provide benefits which can increase value of tourist products on the respective territory. Most products provided are sold as raw materials on remote markets or provide subsistence to forest owners. Having in mind that lots of NWFPs and games locally were processed to valuable and still attractive products, while local natural materials used in traditional architecture were creating attractive traditional buildings and countryside and handicraft items on demand on tourist market), connecting forest products processed locally as a supply to tourist value chains is highly potent for rural economy diversification. 
Added value is occurring in the short value chain, while the increased quality of offered products can replace irrational quantities of harvested raw produces which is the appropriate frame for implementing SFM. In the opposite direction improved and diversified offer of products such as food preserves and gastronomy, souvenirs and animation related to indigenous knowledge have potential to improve tourist products offer. This conclusion should not lure to abandon basic offer of appropriate food and accommodation, and activities which are the core attractor of every certain location. Being territory related, and therefore specific (depends on available forest products/type of forest and related cultural heritage of their processing), combining forest products and services with upgraded or even new tourist product can't be unified in the whole country. The problem will, however appear in regions of Serbia where depopulation swept away traditional knowledge or population is too aged (incapable) to run businesses or in local communities in which due to diverse reasons local communities lack necessary synergy to establish partnerships for providing certain and continuous supply.

Tourism can contribute to SFM if tourism value chains use as a diverse supply all forest products and services available and keep intensity of their use rather low. This implies that starting from logging to activities, tourism ought to be shaped to use local sources instead of imported through establishment of strategic partnerships with local forest owners and forest products processors, as much as local organizers of activities in forests. Both must be well informed on forest ecosystem services, multifunctional forestry and educated to create and apply area-based strategies for rural development, which will be permanently maintained through genuine and operative local partnerships. Success of SFM in regions where tourism is developing will depend on cross-sectoral support (tourism and forestry and rural development portfolio). Set of both national and IPARD measures have windows which can with the addition of appropriate eligibility criteria and scoring with advantages for forests related investments, provide buster for SFM “encouraging” tourism.

\section{ACKNOWLEDGMENT}

The paper represents the results of research within the GCP/SRB/002/GFF project and according to the Agreement of Cooperation No. 0801-417/1 (21/03/2019).

\section{REFERENCES}

Dahdouh-Guebas, F., Mathenge, C., Kairo, J.G. \&Koedam, N. (2000). Utilization of mangrove wood products around Mida Creek (Kenya) amongst subsistence and commercial users. Econ. Bot. 54, 513-527.

Đorđević-Milošević S. \& Hyvaerinen K. Eds. (2020): Economies \& Economic Diversification with the Focus on Rural Tourism. In Economic Diversification Policies and Rural Tourism in South East Europe (pp.15-34), SWG RRD\&GIZ, N. Macedonia, Skopje, http://seerural.org/wp-content/uploads/2020/10/Rural-tourism-study.pdf

Đorđević-Milošević S. \& Milovanović J. (2020a). Agroforestry: Multiplying Benefits from Forest Lands, In: Leal Filho W., Azul A., Brandli L., Özuyar P., Wall T. (eds), Zero Hunger. Encyclopedia of the UN Sustainable Development Goals, Springer, Cham

Đorđević-Milošević S., Milovanović J. (2020b). Alternative Livelihoods Framework: Beyond the Risks and Stress Relief, In: Leal Filho W., Azul A., Brandli L., Özuyar P., Wall T. (eds), Zero Hunger. Encyclopedia of the UN Sustainable Development Goals, Springer, Cham

Đorđević-Milošević, S., Milovanović, J. (2014). Linking Rural Livelihood Diversity and Sustainable Development. Faculty of Applied Ecology Futura Singidunum University Belgrade. 193 pp. ISBN 978-86-86859-35-8

Đorđević-Milošević S. \&Milovanović J. (2012). Održivi turizam u funkciji ruralnog razvoja - Mala poljoprivredna gazdinstva i ruralni turizam u Srbiji, Fakultet za primenjenu ekologiju Futura Beograd, AgroznanjeVršac, FAO Budimpešta

Đorđević-Milošević, S. \&Milovanović, J. (2020c). Pastoralism: Indigenous Way of Mitigating Climate and Poverty Risk, In: Leal Filho W., Azul A., Brandli L., Özuyar P., Wall T. (eds) Zero Hunger. Encyclopedia of the UN Sustainable Development Goals, Springer, Cham

Đorđević-Milošević S., (2020). Rural Economies Diversification Prospects with Focus On Rural Tourism. In South-East Europe (Regional Synthesis) in Economic Diversification Policies and Rural Tourism in South East Europe (pp. 327-369), SWG RRD\&GIZ, N. Macedonia, Skopje, http://seerural.org/wp-content/uploads/2020/10/Rural-tourism-study.pdf 
Đorđević-Milošević S. (2019). Socio-economic perspectives of sustainable forest management and local development in Serbia. Report for the project GCP/SRB/002/GEF: Contribution of sustainable forest management to low emission and resilient development in Serbia (FSP). UN FAO, p. 138

Endara, M.J. \& Coley, P.D. (2011). The resource availability hypothesis revisited: a meta-analysis. Functional Ecology, 25(2), 389-398. DOI: https://doi.org/10.1111/j.1365-2435.2010.01803.x

FAO (2015). Global Forest Resources Assessment 2015 How are the world's forests changing? Second edition, Retrieved September $6^{\text {th }}$, 2020 from http://www.fao.org/3/a-i4793e.pdf

IPARD (2014). Republic of Serbia IPARD Programme for 2014-2020, http://www.minpolj.gov.rs/wp-content/ uploads/datoteke/IPARD/IPARDII\%20final\%20\%20III\%20modification\%20ENG27062019.pdf

Keenleyside C., Đorđević-Milošević S., Hart, S. Ivanov K., Redman M. \& Vidojević D. (2010). Developing a national agri-environment programme for Serbia, IUCN, Retrieved September $25^{\text {th }}, 2020$ from https:// www.iucn.org/content/developing-a-national-agri-environment-programme-serbia-0

Maldonado B., Cabbalero J., Delgado-Salinas A.\&Lira R. (2013). Relationship between use value and ecological importance of floristic resources of seasonally dry tropical forests in the Balasas River Basin, Mexico. Econ Bot 67(1):17-29. DOI: 10.1007/s12231-013-9222-y

MCPFE (1993). Resolution H1 General Guidelines for the Sustainable Management of Forests in Europe, Second Ministerial Conference on the Protection of Forests in Europe 16-17 June 1993, Helsinki/Finland, from https://www.foresteurope.org/docs/MC/MC_helsinki_resolutionH1.pdf

Milovanović, J., Đorđević-Milošević, S. (2016). Biodiversity and Rural Livelihood in the Western Balkans.Faculty of Applied Ecology Futura Singidunum University Belgrade. 244 pp. ISBN 978-86-86859-52-5

Milovanović, J., Šijačić-Nikolić, M., Nonić, M. (2019): Climate change aspects in forest genetic resources conservation in Serbia. In: Šijačić-Nikolić, M., Milovanović, J., Nonić, M. (eds): Forests of Southeast Europe under a Changing Climate: Conservation of Genetic Resources. Springer International Publishing (pp. 319-332). ISBN 978-3-319-95267-3, https://www.springer.com/gp/book/9783319952666

NPRD (2018). The National Program for Rural Development from 2018 to 2020 (“Official Gazette of RS" no. 60/18)

Phumsathan S., Udomwitid S., Pongpattananurak N., Chaisawataree T. \&Tantiwat W. (2017). How to Use Tourism to Support Sustainable Forest Management: A Case Study of the Pha Wang Nam Khiao - Pha Khao PhuLuang Forest Reserve, Thailand. Journal of Tourism and Hospitality Management, 5(3), 126-134. DOI: $10.17265 / 2328-2169 / 2017.06 .003$

Ratknić, T. \& Milovanović, J. (2016). Medicinal herbs as part of the development of sustainable tourism in Nature park "Stara planina". Ekonomika poljoprivrede, LXIII(3), 847-860. DOI: https://doi.org/10.5937/ ekoPolj1603847R

Šijačić-Nikolić, M., Milovanović, J., \&Nonić, M. (2014). Conservation of Forest Genetic Resources. In: Ahuja, M.R. \& Ramawat, K.G. (eds.): Biotechnology and Biodiversity (pp. 103-128). Springer International Publishing

Šijačić-Nikolić, M., Milovanović, J. \& Nonić, M. (eds)(2019). Forests of Southeast Europe under a Changing Climate: Conservation of Genetic Resources. Springer International Publishing AG. Retrieved September $25^{\text {th }}, 2020$ from https://www.springer.com/gp/book/9783319952666. DOI 10.1007/978-3-319-95267-3

Šijačić-Nikolić M., Nonić, M., Lalović, V., Milovanović, J., Nedeljković, J. \&Nonić, D. (2017). Conservation of forest genetic resources: Key stakeholders' attitudes in forestry and nature protection. Genetika 49(3), 875-890 DOI: https://doi.org/10.2298/GENSR1703875S

Wickramasinghe, K. (2013). Ecotourism as a Tool for Sustainable Forest Management in Sri Lanka. Journal of Environmental Professionals. 1(2), 16-29. DOI: http://doi.org/10.4038/jepsl.vli2.5145

Wilkie, M.L., Holmgren, P. \&Castaneda F. (2003). Sustainable forest management and the ecosystem approach: two concepts, one goal. Forest Management Working Papers, Working paper FM 25. Forest Resources Development Service, Forest Resources Division, Retrieved September 6 ${ }^{\text {th }}, 2020$ from http://www.fao. org/forestry/6417-0905522127db12a324c6991d0a53571fa.pdf 